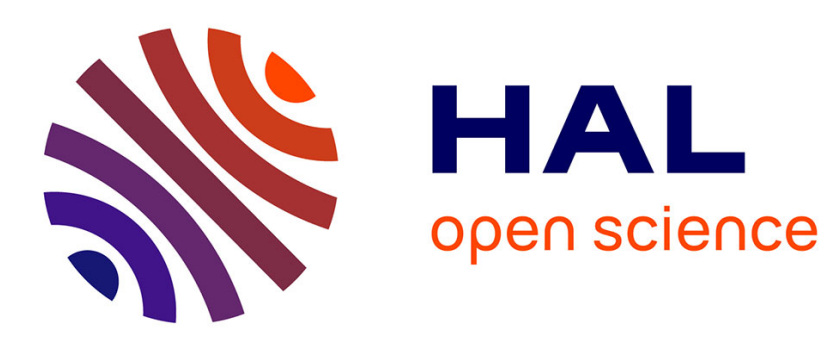

\title{
The Portuguese montado: conciliating ecological values with human demands within a dynamic agroforestry system \\ Paulo Sá-Sousa
}

\section{- To cite this version:}

Paulo Sá-Sousa. The Portuguese montado: conciliating ecological values with human demands within a dynamic agroforestry system. Annals of Forest Science, 2014, 71 (1), pp.1-3. 10.1007/s13595-0130338-0 . hal-01098391

\section{HAL Id: hal-01098391 \\ https://hal.science/hal-01098391}

Submitted on 24 Dec 2014

HAL is a multi-disciplinary open access archive for the deposit and dissemination of scientific research documents, whether they are published or not. The documents may come from teaching and research institutions in France or abroad, or from public or private research centers.
L'archive ouverte pluridisciplinaire HAL, est destinée au dépôt et à la diffusion de documents scientifiques de niveau recherche, publiés ou non, émanant des établissements d'enseignement et de recherche français ou étrangers, des laboratoires publics ou privés. 


\title{
The Portuguese montado: conciliating ecological values with human demands within a dynamic agroforestry system
}

\author{
Paulo Sá-Sousa
}

Received: 20 September 2013 / Accepted: 4 October 2013 / Published online: 30 October 2013

(C) INRA and Springer-Verlag France 2013

In the southwestern Iberian Peninsula, around 3.54.0 million ha of a multi-propose agroforestry system persist, where cork oak (Quercus suber L.), Holm oak [Quercus ilex L. subsp. rotundifolia (Lam.)], or a mixture of both species, coexist with pastures and crops (Acácio et al. 2010; Olea and San Miguel-Ayanz 2006; Pinto-Correira et al. 2011). They are called montado in Portugal and dehesa in Spain but represent quite different structures along a cline from $5 \%$ to $65 \%$ oak tree cover (Castro 2009; Moreno and Pulido 2009; Olea and San Miguel-Ayanz 2006). Montado constitutes simultaneously of a seminatural ecosystem, a multifunctional system and a cultural landscape (Fra Paleo 2010; Pinto-Correia and Godinho 2013; Santos and Thorne 2010). Based on tree density, the montado-dehesa can shape three functional landscapes. First, it is an open woodland where silvopastoral management is aimed not at timber production, but mainly at cork extraction (Castro 2009; Costa et al. 2011). Second, it may resemble a savannah-like oak parkland (30-50 trees per hectare) with multiple uses (forestry goods, seasonal agriculture and livestock grazing), while crown cover per tree was increased to produce acorns (Costa et al. 2010; Moreno and Pulido 2009). The bellow canopy stratum generally comprises pastures and agricultural fields in a rotation scheme that includes fallows, with Mediterranean shrubs artificially kept at low densities (Pinto-Correia et al. 2011). Third, it constitutes a scattered agrosylvopastoral land, often set on Holm oak, which is used primarily for grazing and/or cereal crops (Martín and Fernández-Alés 2006; Plieninger 2007). The montado may be private or communal property (usually belonging to the

\section{Handling Editor: Erwin Dreyer}

P. Sá-Sousa $(\bowtie)$

Instituto de Ciências Agrárias e Ambientais Mediterrânicas, Universidade de Évora, Pólo da Mitra, 7002-554 Évora, Portugal

e-mail: psasousa@uevora.pt municipality), often included in Iberian natural parks (Bugalho et al. 2011; Castro 2009; Moreno and Pulido 2009). In brief, montado plays a role as a panacea system providing ecosystem services (e.g., soil conservation, groundwater recharge and quality protection, carbon sequestration) or other indirect benefits due to its numerous uses through appropriate land-management practices: food, fibres, cork extraction, fuel (firewood, charcoal and cinder), construction (beams and fencing), wood crafts, tanning dyes, livestock food (acorns, tree fodder and pastures) and animal protection (shade and shelter), wild game, aromatic and medicinal plants, edible mushrooms, honey and several other resources (Moreno and Pulido 2009; Olea and San Miguel-Ayanz 2006; Pinto-Correia et al. 2011; Rodríguez-Estévez et al. 2012).

Meanwhile, the Portuguese montado is often associated with cork extraction due to its large economic impact for Portugal, which concentrates more than $33 \%$ of the cork oak surface and accounts for more than $50 \%$ of worldwide cork production and related strategic industries (e.g., wine stoppers, floor/wall coverings) (Castro 2009; Costa et al. 2011).

The extensive livestock accounts for the largest fraction of revenue from the montado (Fragoso et al. 2011), but it also plays a conservation role in the system (e.g., pasture renewal; seed dispersal) (Olea and San Miguel-Ayanz 2006, Plieninger 2007). Thus, the traditional system is highly diversified in terms of livestock breeds (black pigs, cattle, merino sheep and goats). The Iberian black pig is the most appreciated and highly priced livestock, because of the outstanding quality of its cured products when finished on acorns in the montado (Rodríguez-Estévez et al. 2012). However, in recent decades extensive cattle stocking has increased because of direct payments to farmers enrolled under the Common Agricultural Policy (CAP). However, this economic outcome relies on dissociation between the natural environment and its productivity, whereas increasing grazing pressure pushes 
natural oak regeneration to very low densities (Fragoso et al. 2011; Plieninger 2007).

Hunting is another important source of income, the main game species being the red deer (Cervus elaphus hispanicus), wild boar (Sus scrofa), wild rabbit (Oryctolagus cuniculus), red-legged partridge (Alectoris rufa) and migratory birds, e.g., thrushes and doves (Bugalho et al. 2011; Fra Paleo 2010)

Furthermore, montado are considered High Nature Value Farmlands and are included in Annex I of the European Union Habitats Directive (92/43/CEE) (Pinto-Correia and Godinho 2013). As a Mediterranean ecosystem, it is rich in wildlife species (both in flora and fauna) and habitats (Sokos et al. 2013). Here, the most cost efficient and beneficial conservation measures for reptile, bird and mammal species are rotation, intercropping, and the selection of appropriate crops and farming management practices at local levels (Bugalho et al. 2011; Godinho et al. 2011; Santos and Thorne 2010). Oak trees increase the spatial heterogeneity of resources (water, nutrient and temperature), forming a fine mosaic of microhabitats (Moreno and Pulido 2009).

Montado agroecosystems have been shaped by a history of human and ecological disturbances (Martín and FernándezAlés 2006). Understanding the dynamics of these socialecological systems requires an understanding of how human and ecological factors interact (Acácio et al. 2010). Indeed montado has a traditional resilience based on the perseverance of its local stakeholders. However, the system progressively loses its balance when facing unfavorable and global socioeconomic drivers that influence its profitability (e.g., CAP schemes) and tree cover decays in such a way that the montado disappears (Costa et al. 2011; Pinto-Correia and Godinho 2013). Thus, conciliating ecological values with human demands has been a major challenge within this dynamic agroforestry system. For instance, a major dilemma in the Portuguese countryside is polarized between the trend to (1) abandon rural areas; or (2) pursue a technological intensification (e.g., irrigated crops) in these marginal areas, depending both on structural constraints and local circumstances (Bugalho et al. 2011; Pinto-Correia and Godinho 2013). The first trend causes shrub encroachment that breaks down pastures and promotes fire events; the second drastically eliminates tree cover and expands the uniform arable landscape (Acácio et al. 2010). As a consequence, the traditional montado has gradually been replaced by a broader mosaic of single-functional patches (Costa et al. 2011). Moreover, the CAP payment leads to production decisions and resources allocation to be more dependent on market prices and competitive advantages (Fragoso et al. 2011).

Worrying mortality events in cork and Holm oaks have occurred in the montado, but the severity of this decline increased during the 1980s. By that time, the exotic soil borne pathogen Phytophthora cinnamomi was often recovered from declining cork oak stands, and since then it has been considered the main factor associated with decline (CamiloAlves et al. 2013). In the long term it may have a negative impact on the Portuguese cork industry, if reforestation measures are not taken now. Despite the perception of increasingly visible damage to oak woodlands on droughtprone sites, the role of the various environmental factors in their decline is not clear (Costa et al. 2010). Nevertheless, the occurrence of decline is also associated with soil characteristics that interfere with root expansion and water retention (Camilo-Alves et al. 2013).

Finally, montado as well as other Mediterranean agroforestry systems are a genuine heritage of southern European countries (Santos and Thorne 2010; Sokos et al. 2013). The cork oak is so special for Portugal that, since 2011, it has been officially declared the 'National Tree of Portugal' by the National Parliament. Moreover, the regional council of Alentejo (Portugal) is preparing the candidature of the montado as a World Heritage site of UNESCO. Conversely, the Holm oak has not been as favored by national policies and its montado has been declining over the long term. This trend was early suggested by the premonitory title of Fernanda dos Santos Amaro (1992):

\section{Azinheira: a fronteira que nos separa do deserto (Holm}

oak is the boundary that separates us from the desert).

In recent years, the Institute of Mediterranean Agricultural and Environmental Sciences (ICAAM), at the University of Évora (http://www.icaam.uevora.pt/), has been developing applied research on the subject of montado, enhancing an interdisciplinary approach to its multiple topics. Last February, ICAAM sponsored the International Conference 'Montados-Dehesas as High Nature Value Farming Systems'. Thereafter, the Portuguese Green Book of the Montados - a partner document of the Green Book of the Dehesas already produced in Spain - was launched in July. Both documents intend to influence the design of national and European policies that together can contribute to greater recognition of these agroforestry-pastoral systems.

Acácio and Holmgren (2013) review the factors threatening cork oak woodlands and reveal evidence that Cistus shrublands are the successional vegetation stage where alternative pathways can be explored to cope with cork oak regeneration and recruitment. From an ecological perspective, Pereira et al. (2013a) show that the montado ecosystem has such structural prevalence that it still marks its ecological influence even in riverine bird assemblages. On other hand, Pereira et al. (2013b) reveal how the interaction between the presence of woody shrub cover and related passerine birds (e.g., leaf warblers) can mitigate oak defoliation by the sawfly, stressing the relevance of some management activities in the sustainability of the montado. From the human perspective, Surovà et al. (2013) outline the visual landscape preferences 
declared by diverse stakeholders around the montado patterns and depict the main results as future recommendations for landscape policy and management.

Acknowledgments The author would like to thank all fellow authors (ICAAM, CEABN) who have wished to contribute with paper submissions to this issue. This contribution was funded by the ALENT07-0224-FEDER-001744 Gestão da Intensidade de Pastoreio Face à Valorização do Montado como Sistema de Elevado Valor Natural QREN/INALENTEJO.

Funding This contribution was funded by the ALENT-07-0224-FEDER001744 Gestão da Intensidade de Pastoreio Face à Valorização do Montado como Sistema de Elevado Valor Natural QREN/INALENTEJO.

\section{References}

Acácio V, Holmgren M (2013) Pathways for resilience in Mediterranean cork oak land use systems. Ann For Sci. doi:10.1007/s13595-012-0197-0

Acácio V, Holmgren M, Moreira F, Mohren GMJ (2010) Oak persistence in Mediterranean landscapes: the combined role of management, topography, and wildfires. Ecol Soc 15:40. http://www. ecologyandsociety.org/vol15/iss4/art40/

Bugalho MN, Caldeira MC, Pereira JS, Aronson J, Pausas JG (2011) Mediterranean cork oak savannas require human use to sustain biodiversity and ecosystem services. Front Ecol Environ 9:278286. doi:10.1890/100084

Camilo-Alves CS, Clara M, Ribeiro NA (2013) Decline of Mediterranean oak trees and its association with Phytophthora cinnamomi: a review. Eur J For Res 132:411-432. doi:10.1007/s10342-013-0688-z

Castro M (2009) Silvopastoral systems in Portugal - current status and future prospects. In: Rigueiro-Rodríguez A, McAdam J, MosqueraLosada MR (eds) Agroforestry in Europe: current status and future prospects. Springer, Dordrecht, pp 111-126

Costa A, Pereira H, Madeira M (2010) Analysis of spatial patterns of oak decline in cork oak woodlands in Mediterranean conditions. Ann For Sci 67:204. doi:10.1051/forest $/ 2009097$

Costa A, Madeira M, Santos JL, Oliveira AC (2011) Change and dynamics in Mediterranean evergreen oak woodlands landscapes of Southwestern Iberian Peninsula. Landsc Urban Plan 102:164 176. doi:10.1016/j.landurbplan.2011.04.002

Fra Paleo U (2010) The dehesa/ montado landscape. In: Bélair C, Ichikawa K, Wong BYL, Mulongoy KJ (ed) Sustainable use of biological diversity in socio-ecological production landscapes. Montreal: secretariat of the convention on biological diversity. Tech Ser 52:149-151

Fragoso R, Marques C, Lucas MR, Martins MB, Jorge R (2011) The economic effects of common agricultural policy on Mediterranean montado/dehesa ecosystem. J Policy Model 33:311-327. doi:10. 1016/j.jpolmod.2010.12.007

Godinho S, Santos AP, Sá-Sousa P (2011) Montado management effects on the abundance and conservation of reptiles in Alentejo, Southern Portugal. Agrofor Syst 82:197-207. doi:10.1007/s10457-010-9346-3
Martín AV, Fernández-Alés A (2006) Long term persistence of dehesas. Evidences from history. Agrofor Syst 67:19-28. doi:10.1007/ s10457-005-1110-8

Moreno G, Pulido F (2009) The functioning, management and persistence of dehesas. In: Rigueiro-Rodríguez A, McAdam J, Mosquera-Losada MR (eds) Agroforestry in Europe: current status and future prospects. Springer, Dordrecht, pp 127-160

Olea L, San Miguel-Ayanz A (2006) The Spanish dehesa: a traditional Mediterranean silvopastoral system linking production and nature conservation. In: Lloveras J, GonzalezRodriguez A, Vazquez-Yañez O, Piñero J, Santamaria O, Olea L, Poblaciones MJ (ed) Sustainable grassland productivity. Grassland science in Europe vol. 11, Badajoz, Soc. Española para el Estudio de los Pastos, pp 3-13 http://www.fao.org/ fileadmin/templates/agphome/images/iclsd/documents/wk1 c5 radomski.pdf

Pereira P, Godinho C, Gomes M, Rabaça JE (2013a) The importance of the surroundings: are bird communities of riparian galleries influenced by agroforestry matrices in SW Iberian Peninsula? Ann For Sci. doi:10.1007/s13595-012-0228-x

Pereira P, Godinho C, Roque I, Marques A, Branco M, Rabaça JE (2013b) Time to rethink the management intensity in a Mediterranean oak woodland: the response of insectivorous birds and leaf-chewing defoliators as key groups in the forest ecosystem. Ann For Sci. doi:10.1007/s13595-012-0227-y

Pinto-Correia T, Godinho S (2013) Changing agriculture-changing landscapes: what is going on in the High Valued montado. In: Ortiz-Miranda D, Moragues-Faus A, Arnalte-Alegre E (ed) Agriculture in Mediterranean Europe: between old and new paradigms. Res Rural Sociol Dev 19:75-90. doi:10.1108/S10571922(2013)0000019006, Emerald, Bingley, UK

Pinto-Correia T, Ribeiro N, Sá-Sousa P (2011) Introducing the montado, the cork and holm oak agroforestry system of Southern Portugal. Agrofor Syst 82:99-104. doi:10.1007/s10457-011-9388-1

Plieninger T (2007) Compatibility of livestock grazing with stand regeneration in Mediterranean holm oak parklands. J Nat Conserv 15:1-9

Rodríguez-Estévez V, Sánchez-Rodríguez M, Arce C, García AR, Perea JM, Gómez-Castro AG (2012) Consumption of acorns by finishing Iberian pigs and their function in the conservation of the dehesa agroecosystem. In: Kaonga ML (ed) Agroforestry for biodiversity and ecosystem services - science and practice. InTech, Rijeka, pp 1-22

Santos MJ, Thorne JH (2010) Comparing culture and ecology: conservation planning of oak woodlands in Mediterranean landscapes of Portugal and California. Environ Cons 37:155-168. doi:10.1017/S0376892910000238

Santos Amaro F dos (1992) Azinheira: a fronteira que nos separa do deserto (Holm oak is the boundary that separates us from the desert). In: Guia agro-pecuário. Europa América, Lisbon, pp 51-56

Sokos CK, Mamolosa AP, Kalburtji KL, Birtsasc PK (2013) Farming and wildlife in Mediterranean agroecosystems. J Nat Cons 21:81-92. doi:10.1016/j.jnc.2012.11.001

Surová D, Pinto-Correia T, Marušák R (2013) Visual complexity and the montado do matter: landscape pattern preferences of user groups in Alentejo, Portugal. Ann For Sci. doi: 10.1007/s13595-013-0330-8 